Pak. J. Anal. Environ. Chem. Vol. 22, No. 1 (2021) 180 - 189

\title{
Paper Waste Management: Extraction of Fermentable Sugar from Lignocellulosic Waste Paper
}

\author{
Asghar Hayat ${ }^{1}$, Sabika Rafiq ${ }^{2}$, Mahboob ur Rehman ${ }^{1}$, Farzana Kausar ${ }^{3}$, \\ Zafar Mahmood Khalid ${ }^{1}$ and Pervez Anwar ${ }^{1,4}$ \\ ${ }^{1}$ Department of Biological Sciences, International Islamic University Islamabad, Pakistan. \\ ${ }^{2}$ Department of Microbiology and Molecular Genetics, The Women University, Multan, Pakistan. \\ ${ }^{3}$ PirMehar Ali Shah Arid, Agriculture University, Rawalpindi, Pakistan. \\ ${ }^{4}$ Department of Biochemistry and Molecular Biology, University of Sialkot, Pakistan. \\ *Corresponding Author Email: sabikar46@gmail.com \\ Received 12 September 2020, Revised 02 June 2021, Accepted 08 June 2021
}

\begin{abstract}
The utilization of paper on a commercial scale is increasing day by day throughout the world that produces million of tons of paper waste yearly and burdened for landfills. The present study focuses on the exploitation of waste papers (office paper, newspaper and tissue paper) as a cheapest alternative source of energy to extract fermentable sugar by applying chemical and enzymatic pretreatments. The quantification of released sugar was analyzed by spectrophotometer and high performance liquid chromatography refractive index (HPLC-RI) detector. Cellulose (12 FPU/g) and $\beta$-glucosidase (12 FPU/g) was found to be effective for the extraction of fermentable sugar from paper waste. The contents of cellulose $\left(\mathrm{C}_{6} \mathrm{H}_{10} \mathrm{O}_{5}\right) \mathrm{n}$, hemicellulose $\left(\mathrm{C}_{5} \mathrm{H}_{10} \mathrm{O}_{5}\right) \mathrm{n}$ and lignin $\left(\mathrm{C}_{9} \mathrm{H}_{10} \mathrm{O}_{2}, \mathrm{C}_{10} \mathrm{H}_{12} \mathrm{O}_{3}, \mathrm{C}_{11} \mathrm{H}_{14} \mathrm{O}_{4}\right)$ found in office paper were $40 \%, 32.5 \%, 22.5 \%$, in newspaper $46.5 \%, 30.5 \% 22.5 \%$, and in tissue paper $62 \%, 22 \%, 15.5 \%$, respectively. The percentages of sugar contents assessed in this study were $62 \%$ in tissue paper and $46.5 \%$ in newspaper and $40 \%$ in office papers. Among the three substrates, tissue paper $(23.4 \mathrm{mg} / \mathrm{mL})$ released a significant amount of glucose $\left(\mathrm{C}_{6} \mathrm{H}_{6} \mathrm{O}_{12}\right)$, whereas newspaper $(20.8 \mathrm{mg} / \mathrm{mL})$ and office paper $(19.6 \mathrm{mg} / \mathrm{mL})$ released less amount of sugar. This research of acid pre-treatment and enzymatic hydrolysis was an efficient method to improve glucose conversion from lignocellulosic waste. Furthermore, this approach can be proved the first step towards the sustainable production of bioethanol from wastepaper-extracted sugar.
\end{abstract}

Keywords: Bioconversion, Wastepaper, Glucose, Spectrophotometer, Bioethanol.

\section{Introduction}

Paper waste is a major component of municipal and institutional solid waste and more than 400 million tons of paper waste is produced annually [1]. Paper waste contains more than $85 \%$ cellulose, which an alternative source of fermentable sugar (glucose and xylose) as well as an energy source [2]. Paper waste as a renewable source of energy has multiple applications for the extraction of fermentable sugar, which can be applied for the production of valuable products such as biofuels, bioethanol, biolipids, bioplastic as well as bacterial biomass and biohydrogen gas [3]. Extraction of sugar from paper waste increases the production of biofuels and causes the reduction of municipal solid waste as a promising approach towards sustainable energy. 
Fossil fuel is an economical source of energy as global energy demand is dramatically increasing in response to rapid social and economic growth. Dependence on conventional fossil energy sources, including coal, natural gas and oils for the production of fuels are not enough to fulfil the requirement of humans due to the increase in population and excessive use of fuels increased the demand for fossils [4]. It is expected that annual crude oil production will reduce from 25 billion barrels to just about 5 billion barrels in 2050. So there is a need to explore other sources of energy [5]. Energy Information Administration (EIA) estimated that in 2005 the production of fossils fuel reached over 72 million barrels per day in the whole world and it is increasing day by day and reached over to 75 million barrels per day. Due to this scenario, the prices of fossil fuel fluctuate at a very high rate due to increased demand and supply [6]. The depletion of fossils fuel is the main challenge for future [7]. Extreme use of crude oil is not only diminishing resources, but it is also slowly increasing the level of carbon dioxide in atmosphere which is responsible for global warming which effect on human normal life and their financial system [8].

From a decade of years, people and governments which want to solve environmental problems and energy safety have a guide to the encouragement of renewable energy sources. Biomass is one of the big alternates of fossils fuel which can play an important role in a more varied and sustainable energy blind [9]. United State annually produces 7.4 million tons of biomass which could deliver up to 5.2 million megawatt hours of power electricity and 250 million gallons of gasoline [10]. EU has the target of producing $20 \%$ of the world energy from renewable sources till to 2020 and according to Renewable Energy Action Plan (NREAPs) more than a third of the EU electricity consumption will come from renewable energy sources and the share of renewable energy sources in transport is projected to $111.2 \%$ in 2020. Brazilian sugarcane ethanol is a world energy product that is fully competitive with motor gasoline and good for replication in many countries [11]. The global production of biofuel has dramatically increased in recent years from 18.2 to 60.6 billion liters from 2000 to 2007 by using cheap substrate [12]. It is estimated that the world has produced about 87 Giga Liters of biofuel in 2008. Pakistan Environmental Protection Agency (PEPA) has reported in 2005 that $1.896 \mathrm{~kg} / \mathrm{house} /$ day to $4.29 \mathrm{~kg} / \mathrm{house} /$ day produces waste in major cities.

Biofuel is considered as a cheapest alternative source of energy, which can be sustainably produced by reducing low cost agricultural lingo cellulosic waste materials. Biomass is a big source of energy and having vast availability. Biomass can be utilize to produce many types of energies, including thermal energy, biofuels like bioethanol, biogas and biodiesel. Most energy production circles depend upon cellulosic biomass because it has near-zero greenhouse emissions found everywhere, low price and environment friendly [13]. Different methods and techniques can be worked on to gain energy from biomass [14]. The production of bio-fuel from lingo-cellulosic material is the second generation phenomena, in this process, the lignocellulosic material that has six carbon sugars is converted into simple sugar and then ethanol by fermentation [15]. Conversion of lignocellulosic material to alcohol basically consists of four basic steps like pretreatment, enzymatic hydrolysis, fermentation and alcohol purification. During the process of bio-fuel production, the process first needs to address the quick elimination of lignin and hemicelluloses by the step of pretreatment. In recent time it has been confirmed that the 
dilute acid pre-hydrolysis could achieve better results in low time and get better cellulose hydrolysis. But pretreatment working surrounding must be customized to the particular chemical and structural composition of the biomass [16].

One of the cheap and readily available sources of biomass is waste paper. Waste paper is lignocellulosic material used as solid fuel and can give $16 \mathrm{MJ} / \mathrm{Kg}$ of energy. The cellulosic material can be hydrolyzed via chemical or enzyme and fermented to produce biomaterial and biofuels [17]. After working, the papers are thrown everywhere, which make the environment polluted, waste the biomass and increase the cost for the demand of new paper. The recycling of newspaper can save the environment and also will reduce the cost of paper and will provide another feedstock for the production of biofuel. The problem in this issue is that the requirements for the production of biofuel from paper are that the temperature needs to be controlled and enzymes used must give sufficient yield [2].

The method discussed here is known as Simultaneous Saccharification and Fermentation (SSF). It utilizes cellulase enzyme to break down the cellulose and yeast to ferment the resulting glucose. The ethanol produced can be used in blended form with gasoline as well as in neat form. Ethanol burns to give out less harmful gasses into the environment, it is a renewable and clean energy [18]. Hydrolysis of the cellulosic material in fermentable sugar is the first move for the manufacture of biofuel. Pretreatment of cellulosic biomass is complicated than the hydrolysis of polysaccharides likes starch. Different chemicals are used for the hydrolysis of cellulose, such as Sulfuric acid, Hydrochloric acid, heterogeneous solid acids, sulfonated carbonaceous based acids, polymer based acids and magnetic solid acids [19]. Brown rots are microorganisms that are used for the treatment of waste paper that attack cellulose. The cellulase enzyme, which is produced by a fungus such as (Trichoderma, Penicillium, Aspergillus, Schizophyllum and chrysosporium) and bacteria (Bacillus, Thermomonospora, Ruminococcus, Bacteriodes, Clostridium, Cellulomonas and Streptomyces) were used. The enzymatic hydrolysis process is low in cost as compared to other methods. The products of hydrolysis are usually reducing sugars, including glucose [20].

Keeping in view the economic importance of lignocellulosic biomass, the present study was carried out for the optimization of dilute sulfuric acid pretreatment condition and enzymatic hydrolysis of waste paper with cellulose for the production of fermentable sugars under different temperature and reaction time period. This fermented sugar analyzed by using High Performance Liquid Chromatography (HPLC).

\section{Materials and Methods}

The study was conducted at Biotechnology Laboratory in Pir Mehr Ali Shah (PMAS) Arid Agricultural University Rawalpindi and the department of Bioinformatics and Biotechnology, International Islamic University Islamabad.

\section{Collection of Substrate}

Office paper, newspaper and tissue paper, which are cellulosic feedstock used as a substrate for the extraction of fermentable sugar for biofuel, were collected from local areas of district Islamabad, Pakistan (Fig. 1a-c).
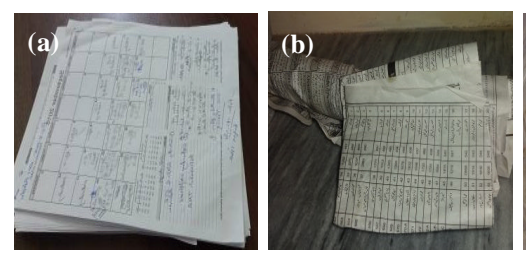

News Paper

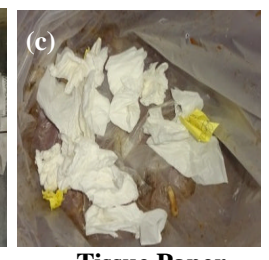

Tissue Paper

Figure 1. Sources of lignocellulosic feedstocks (a-c) 


\section{Sample Preparation}

The substrate was collected in a soilfree and fungus-free condition and shredded into small pieces by using a machine (AS1225CD AURORA). Further substrate was converted into small pieces (mesh size between 40 and $100 \mathrm{~mm}$ ), then dried in sunlight and stored in sealed polyethene bags.

\section{Chemical Analysis of the Substrate Estimation of cellulose}

Substrate composition and its properties were determined by analyzing by cellulose content and total carbohydrate concentration in the substrate. The cellulose content was estimated by Gopal and Ranjhan, 1980 method with some variations. The Amount of cellulose content (\%) was calculated by the following formula [21]. In this method, one gram $\left(\mathrm{W}_{1}\right)$ of a sample (office paper) was taken into a round bottom flask and added $30 \mathrm{~mL}$ of $80 \%$ acetic acid. The sample with acetic acid mixed with $2 \mathrm{~mL}$ of concentrated nitric acid and refluxed for 20 min. After this, the sample was filtered and residues were dried by using the oven at $105^{\circ} \mathrm{C}$ for a night and again weighted the sample $\left(\mathrm{W}_{2}\right)$. The sample was then heated and converted in ash by using muffle furnace at $550^{\circ} \mathrm{C}$ for 6 hours and weighed again $\left(\mathrm{W}_{3}\right)$. Similarly processes were done for newspaper and tissue paper.

Cellulose contents $(\%)=\frac{\mathrm{W}_{2}-\mathrm{W}_{3}}{\mathrm{~W}_{1}} \times 100$

\section{Estimation of lignin}

Estimation of lignin was carried out in accordance with the method described by Milagres (1994). By applying formula given below, the lignin content was calculated [22], and the same processes of estimation of lignin were done in newspaper and tissue paper.

Lignin contents $(\%)=\frac{\mathrm{W}_{2}}{\mathrm{~W}_{1}} \times 100$

\section{Estimation of hemicelluloses}

Estimation of hemicellulose was carried out by simple calculation.

Cellulose + Lignin $-100=$ Hemicelluloses

Optimization of Pretreatment Process

The pre-treatment optimization for the substrate was carried out by using final concentrations of dilute sulphuric acid ranging from $0.5,0.75$ and $2 \%(\mathrm{w} / \mathrm{w})$ at $90^{\circ} \mathrm{C}, 100^{\circ} \mathrm{C}$ $\& 110^{\circ} \mathrm{C}$ with residence times of 15,30 and 45 minutes, in order to know the best conditions at which substrate give maximum fermentable sugars. The pretreated biomass was adjusted to $\mathrm{pH} 5.0$ with $10 \mathrm{M} \mathrm{NaOH}$ before enzymatic Saccharification [17]. The maximum amount of cellulose was released during pre-treatment process, further the solution was taken for hydrolysis.

\section{Enzymatic Saccharification and Hydrolysis}

Maximum cellulose released during the acidic pretreatment and hydrolyzed by cellulose degrading enzymes released by bacteria. After dilute acid pretreatment, enzymatic hydrolysis at the solid loading of $5 \%$ dry mass (DM, w/w) of each sample was performed using cellulase and $\beta$-glucosidase for a maximum of $72 \mathrm{~h}$ in a water bath at $37^{\circ} \mathrm{C}$ separately. Sodium citrate buffer $(50 \mathrm{mM}, \mathrm{pH}$ 4.8 ) is used in the mixture to maintain the $\mathrm{pH}$ at 4.8 [23].

\section{Detoxification with $\mathrm{Ca}(\mathrm{OH})_{2}$}

Detoxification of pretreated hydrolyzate of samples was carried out in a $250 \mathrm{~mL}$ flask in an incubated water bath shaker with $\mathrm{Ca}(\mathrm{OH})_{2}$. Involves increasing the $\mathrm{pH}$ of the hydrolyzates to $9,10,11$ or 12 , keeping up to 90 min at different temperatures of 30,45 and $60{ }^{\circ} \mathrm{C}$, followed by readjustment of the $\mathrm{pH}$ to 5 [24]. 


\section{Estimation of Total Releasing Sugar}

Total releasing sugar contents of substrate were measured by adding concentrated $\mathrm{H}_{2} \mathrm{SO}_{4}$ (purity 97\%) in each sample with specific concentrations and leftover for $20 \mathrm{~min}$ at room temperature.

The optical density (OD) of total released sugar was analyzed by spectrophotometer at $470 \mathrm{~nm}$ against blank [25]. The standard curve for the estimation of the sugar by Spectrophotometer is shown in Fig. 4.

\section{Analytical Procedure}

The total reducing sugars of each sample were determined separately by DNS (Dinitrosalicylic acid) method using glucose as the standard and quantification of released sugar was analyzed by High Performance Liquid Chromatography-Refractive Index (HPLC-RI) detector. The analysis of sugar was carried out at a temperature $35^{\circ} \mathrm{C}$ and the

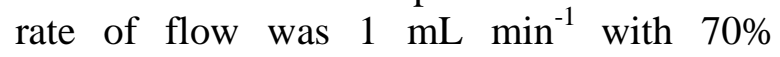
acetonitrile and $25 \%$ of water, mixture as a mobile phase. Samples were centrifuged at $4000 \mathrm{rpm}$ for $10 \mathrm{~min}$. Residues were filtered and diluted 8-10 times before inserted in HPLC.

\section{Statistical Analysis}

The data obtained was statistically analyzed by Analysis of Variance (ANOVA) by using MS Excel software.

\section{Results and Discussion Substrate Evaluation}

Waste paper is made up of cellulose, hemicellulose and lignin which can be hydrolyzed via chemical or enzyme and fermented to produce biofuel. The current research has been conducted on waste paper to hydrolyze by dilute sulfuric acid pretreatment.
The chemical analysis of substrates revealed that in office paper, cellulose $40 \%$, hemicellulose $32.5 \%$ and lignin $22.5 \%$ were assessed. In the newspaper, cellulose $46.5 \%$, hemicellulose $30.5 \%$ and lignin $22.5 \%$ were observed, while in tissue paper, cellulose $62 \%$, hemicellulose $22 \%$ and lignin $15.5 \%$ were found (Table 1). The suitable substrate for maximum cellulosic contents was found in tissue paper. The results are in accordance with Kim et al,. [26] their results showed that yellow waste paper contains cellulose $37 \%$ and hemicellulose $26 \%$. According to Foyle et al., [27], compositional analysis of lignocellulosic waste paper contains $37 \%$ cellulose, $28 \%$ hemicellulose and $21 \%$ lignin. Jung et al.,[28] proved that the waste paper (newspaper) contains $57 \%$ cellulose, $8.4 \%$ hemicellulose and $17.2 \%$ lignin and office paper contained $59.2 \%$ cellulose and $9.0 \%$ hemicellulose and $17.5 \%$ ash content and Lee et al., [29] proved that waste paper consists of $16-22 \%$ of lignin and $60-75 \%$ of cellulose.

Table 1. Presence of cellulose, hemicellulose and lignin contents in substrates.

\begin{tabular}{lccc}
\hline \multicolumn{1}{c}{ Samples } & $\begin{array}{c}\text { Cellulose } \\
\boldsymbol{\%}\end{array}$ & $\begin{array}{c}\text { Hemicellulose } \\
\boldsymbol{\%}\end{array}$ & $\begin{array}{c}\text { Lignin } \\
\boldsymbol{\%}\end{array}$ \\
\hline Office paper & $40 \pm 2.5$ & $32.5 \pm 2.5$ & $22.5 \pm 2.5$ \\
Newspaper & $45 \pm 1.5$ & $30.5 \pm 5$ & $25 \pm 5$ \\
Tissue paper & $60 \pm 2$ & $25 \pm 5$ & $15 \pm 5$ \\
\hline
\end{tabular}

*Data presented in mean \pm SD for three different samples

\section{Optimization of Acidic Pretreatment of} Substrate

In pre-treatment with different concentrations of sulfuric acid, cellulosic biomass will change the structure to make cellulose become more accessible to enzymes that convert carbohydrate polymers to fermentable sugars and with more production [30]. Our study recorded the highest concentration of sugar $(48.8 \%)$ with $0.5 \%$ concentration of sulfuric acid treatment from a newspaper, and the lowest sugar concentration (45.2\%) was recorded for the office paper on same temperature and time interval (Fig.2a-c). 

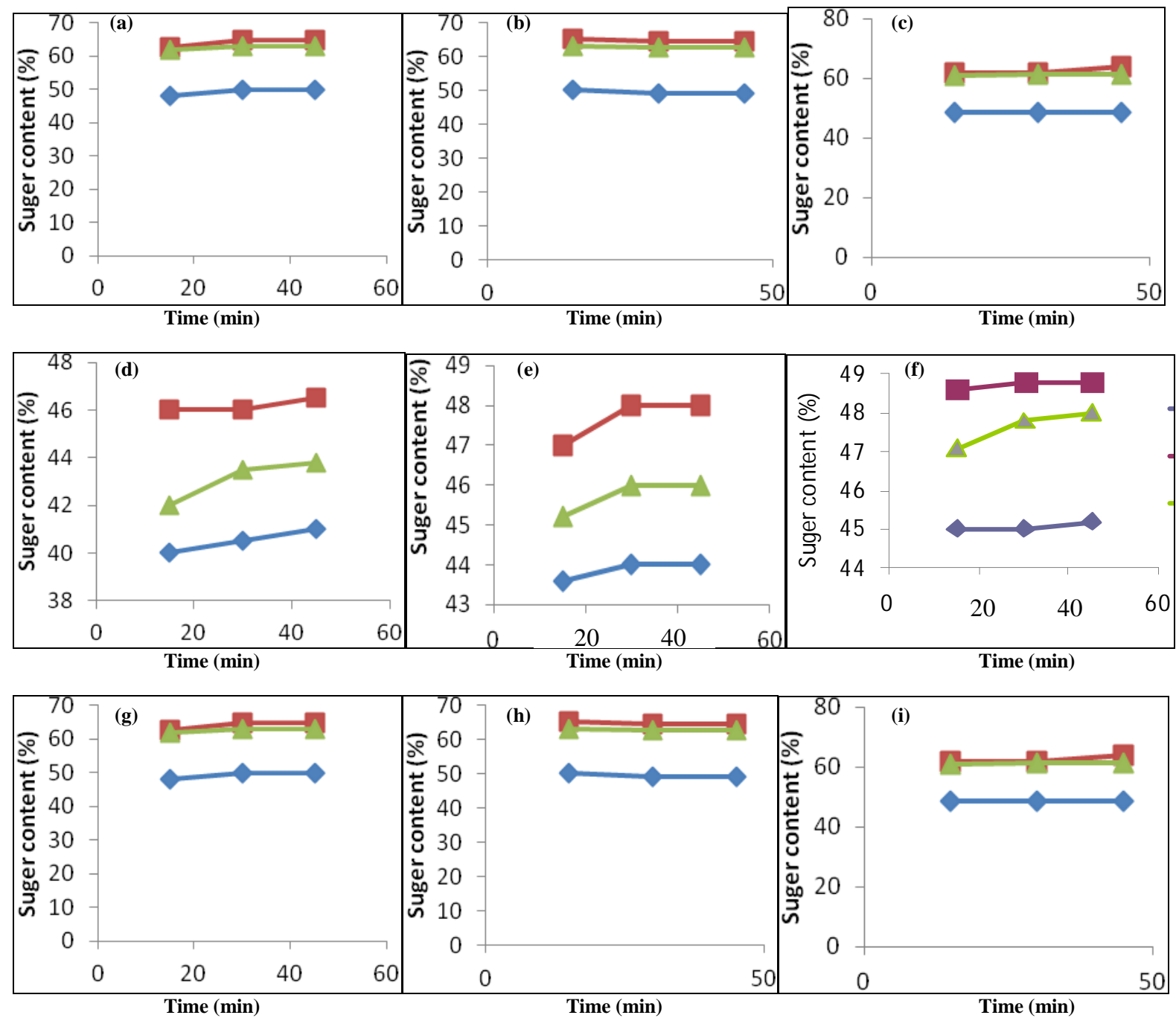

Figure 2. Extraction of sugar at different concentration of sulfuric acid at various temperatures

While the highest concentration of sugar contents $(56 \%)$ was found in the substrate (newspaper) and the lowest sugar concentration $(47.5 \%)$ was observed from the office paper at $0.75 \%$ concentration of dilute sulfuric acid (Fig. 2d-f). The highest concentration of sugar contents $(65 \%)$ was recorded in the substrate (newspaper) at $2 \%$ concentration of sulfuric acid. And lowest sugar concentration $(50 \%)$ was recorded for the office paper (Fig. 2 g-i). During optimization of dilute sulfuric acid, it was found that the optimum condition were about $2 \%$ sulfuric acid, $100^{\circ} \mathrm{C}$ and 30 minutes for removal of $65 \%$ of sugar contents from newspaper and tissue paper but the removal of sugar contents from office paper was $50 \%$. These results are similar to Gupta et al., [31] reported that the optimum condition were about $2 \%$ sulfuric acid, $150^{\circ} \mathrm{C}$ and 15 min for removal of $60 \%$ hemicellulose and $75 \%$ lignin from the newspaper. In another study, Dubey et. al., [32] reported the optimum condition for acid hydrolysis of waste paper was $0.50 \mathrm{~N}$ sulfuric acid at $120^{\circ} \mathrm{C}$ for $2 \mathrm{~h}$.

\section{Enzymatic Hydrolysis}

In the present study, after acidic pretreatment for the enzymatic 
saccharification of the substrate, the cellulase and $\beta$-glucosidase enzyme with the activity of $12 \mathrm{FPU} / \mathrm{g}$ and $23 \mathrm{U} / \mathrm{g}$ were used. $5 \%(\mathrm{w} / \mathrm{v})$ substrate (office paper) hydrolyzed with enzymes on given time and released sugar 5.5 $\mathrm{mg} / \mathrm{mL}, 7.5 \mathrm{mg} / \mathrm{mL}, 9.5 \mathrm{mg} / \mathrm{mL}, 12.2 \mathrm{mg} /$ $\mathrm{mL}, \quad 19.6 \mathrm{mg} / \mathrm{mL}$ and $18.3 \mathrm{mg} / \mathrm{mL}$, respectively were observed (Fig. 3a).
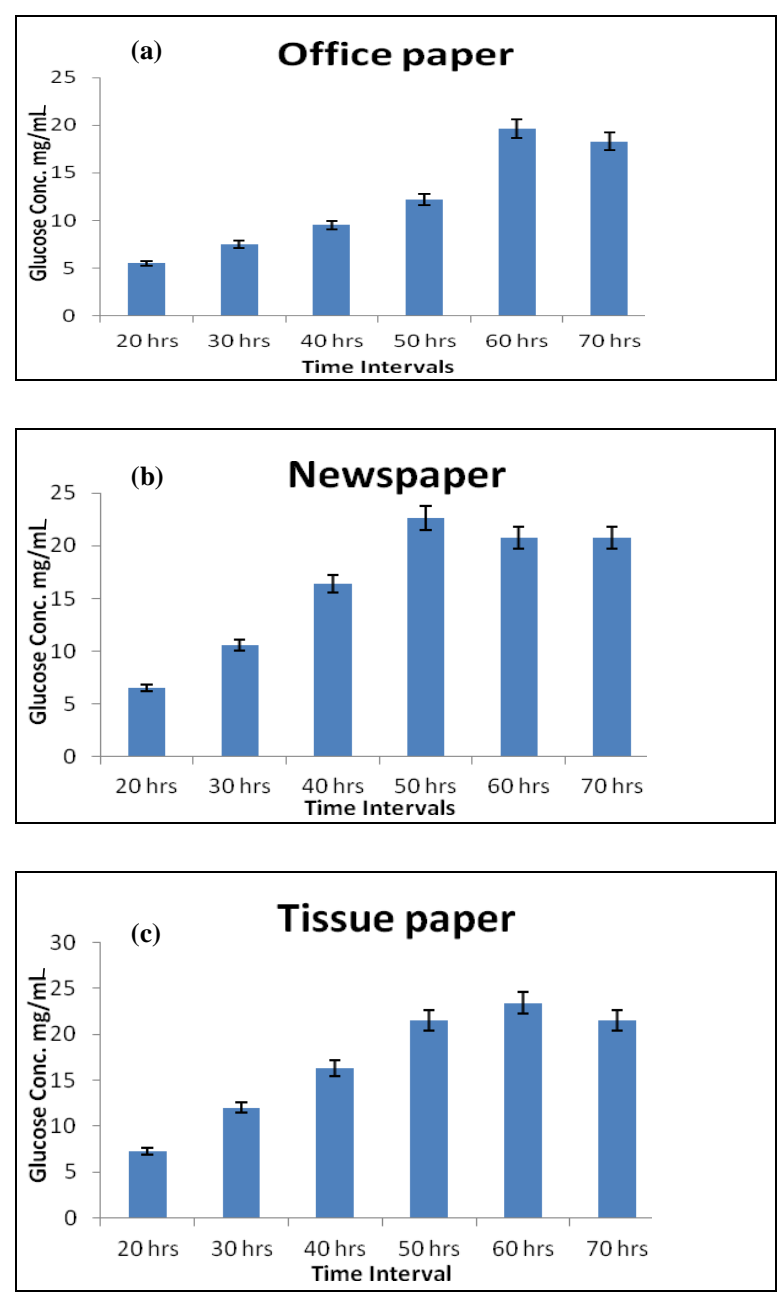

Figure 3. Production of glucose at different time intervals with specific enzymes $12 \mathrm{FPU} / \mathrm{g}$ and substrate $23 \mathrm{U} / \mathrm{g}$ concentration

The same process of enzymatic saccharification was carried out on another substrate (newspaper). The same amounts of enzymes were applied on various time periods (T1, T2, T3, T4, T5 \& T6) and resulted in sugar $6.5 \mathrm{mg} / \mathrm{mL}, 10.6 \mathrm{mg} / \mathrm{mL}, 16.4 \mathrm{mg} / \mathrm{mL}$, $22.6 \mathrm{mg} / \mathrm{mL}, 20.8 \mathrm{mg} / \mathrm{mL}$ and $20.4 \mathrm{mg} / \mathrm{mL}$, respectively were recorded (Fig. 3b). How longer an enzyme incubated with its substrate, the greater the number of products will be formed. Still, the rate of product formation is not a linear function of time incubation, as all enzymes are protein in nature suffer denaturation and hence losing a significant amount of activity over the period of incubation.

Similarly the process of enzymatic saccharification was carried out on other substrate (tissue paper) and released sugar 7.2 $\mathrm{mg} / \mathrm{mL}, 12 \mathrm{mg} / \mathrm{mL}, 16.3 \mathrm{mg} / \mathrm{mL}, 21.5 \mathrm{mg} /$ $\mathrm{mL}, 23.4 \mathrm{mg} / \mathrm{mL}$ and $21.5 \mathrm{mg} / \mathrm{mL}$ observed, respectively (Fig. 3c). Optimum conditions for more sugar released from the office paper was $60 \mathrm{~h}$ (T5), while for the newspaper $48 \mathrm{~h}$ (T4) and for tissue paper $60 \mathrm{~h}$ (T5).

The results are in accordance with Elliston et. al., [33] reported that the use of $16 \mathrm{FPU} / \mathrm{g}$ cellulase, and $30 \mathrm{U} / \mathrm{g} \beta$-glycosidase on different time periods ( $\mathrm{H} 1 \& \mathrm{H} 2)$ on $5 \%$ substrate $(\mathrm{w} / \mathrm{v})$ resulted in a sugar concentration of $7.5 \mathrm{mg} / \mathrm{mL}$ and $14.4 \mathrm{mg} / \mathrm{mL}$, respectively. Kuhad et al., [34] also reported that $\beta$-glycosidase (60 Ug-1), exoglucanase (20 U g-1) and xylanase (80 U g-1) released a maximum amount of $14.64 \mathrm{~g} \mathrm{L-1}$ sugar [35]. Hilloise indicated in her study that the use of enzyme 5.2, 7.8 and 10.4 FPU/g on different hydrolysis time 24,48 and $72 \mathrm{~h}$ on the substrate $(2.25,3.0$ and $3.75 \mathrm{~g})$ maximum glucose concentration was obtained $23 \mathrm{~g} / \mathrm{L}$.

\section{Analysis of Glucose Through UV Visible Spectrophotometer}

Through enzymatic hydrolysis resulted sugar (glucose and xylose) were recorded. Sugar yield from wastepaper analyzed through UV visible Spectrophotometer showed the high amount of glucose $23.4 \mathrm{mg} / \mathrm{mL}$ at $60 \mathrm{~h}$ retention time with 0.15378 OD in substrate (tissue paper), while in newspaper low 
concentration of glucose $20.8 \mathrm{mg} / \mathrm{mL}$ was recorded as compared to tissue paper on same retention time. Similarly, in the office paper, the amount of glucose was $19.6 \mathrm{mg} / \mathrm{mL}$ on 60 $\mathrm{h}$ retention time (Table 2). Optical density decreased for newspaper and office paper waste due to the reason enzymes (cellulase and $\beta$-glucosidase) showed less hydrolytic activity against newspapers and office papers, whereas enzymes showed high activity towards tissue paper waste substrate.

Table 2. Analysis of glucose at $60 \mathrm{~h}$ retention time through UV- Visible spectrophotometer.

\begin{tabular}{lcc}
\hline \multicolumn{1}{c}{ Sample } & Optical Density & $\begin{array}{c}\text { Glucose concentration } \\
(\mathbf{m g} / \mathbf{m L})\end{array}$ \\
\hline Office paper & 0.14732 & $19.6 \pm 1.16$ \\
Newspaper & 0.14936 & $20.8 \pm 2.21$ \\
Tissue paper & 0.15378 & $23.4 \pm 0.65$ \\
\hline
\end{tabular}

\section{Analysis of Glucose Through HPLC}

After the pretreatment and enzymatic hydrolysis, the samples were subjected for HPLC determination of glucose. For that purpose, first glucose was analyzed spectrophotometrically and the regression equation was drawn as shown in Fig. 4. Later on, standard glucose was run on HPLC and compared with test samples to ensure the presence of glucose. The standard peak of glucose is shown in the HPLC chromatogram (Fig. 5).

$$
\mathrm{C} 2=0.00071+0.168 \mathrm{C} 1
$$

$$
\mathrm{S}=0.003917 \quad \mathrm{R}-\mathrm{Sq}=99.7 \% \quad \mathrm{R}-\mathrm{Sq}(\operatorname{adj})=99.6 \%
$$

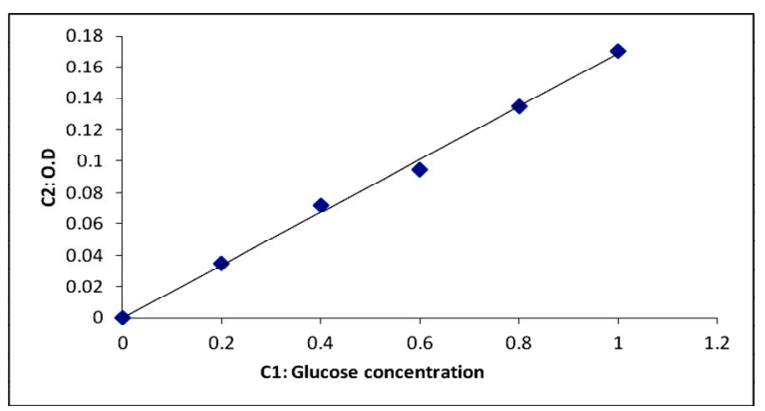

Figure 4. Standard curve and regression equation for glucose

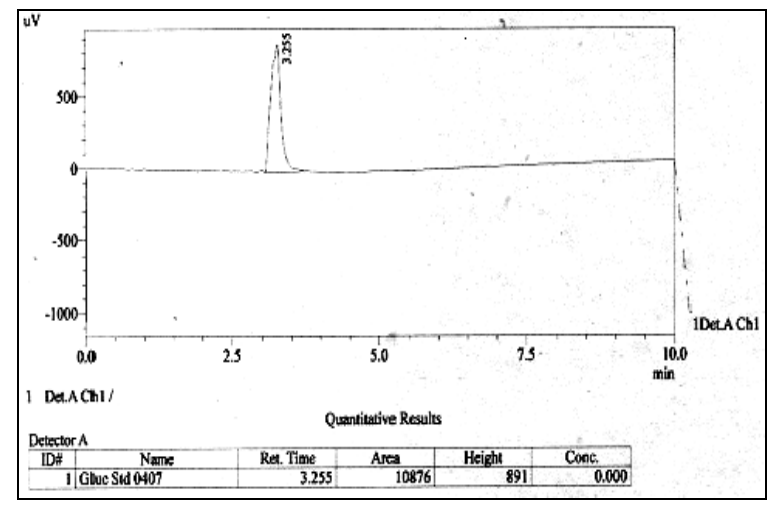

Figure 5. Standard peak for glucose analysis

Through enzymatic hydrolysis, Sugar (glucose and xylose) yield obtained from wastepaper were analyzed through HPLC, which showed a high amount of glucose (22$25 \mathrm{mg} / \mathrm{mL}$ ) at 3.5 retention time with 224839 peak area in the substrate (tissue paper). In comparison, newspapers yield less sugar concentration $(20-24 \mathrm{mg} / \mathrm{mL})$ at 3.571 retention time with a peak area 361581 as compared to tissue paper. Similarly, in the office paper, the concentration of glucose was $18-21 \mathrm{mg} / \mathrm{mL}$ on 3.317 retention time with 324181 peak area.

In the background of these findings, it was observed that acidic pretreatment and enzymatic scarification is an effective method for the conversion of cellulosic biomass into fermentable sugar contents. This research will be further accomplished to achieve a high recovery of fermentable sugar for the production of biofuels and bioethanol.

\section{Conclusion}

The present study deals with the utilization of municipal paper waste to extract fermentable sugar for biofuel production. Waste paper utilization is an efficient way to achieve energy conservation and minimize waste. This study showed that acidic pretreatment and enzymatic scarification is an effective method for converting cellulosic biomass into fermentable sugar contents. The 
highest cellulose content obtained by dilute sulfuric acid pretreatment was estimated to be $62 \%$. By operating the pretreatment at optimum conditions that were $2 \%$ sulfuric acid, $100^{\circ} \mathrm{C}$ and 30 min resulting in $65 \%$ of sugar contents from tissue paper and enzymatic hydrolysis of tissue paper show the maximum amount of sugar in a short time period and less sulfuric acid loading subsequently reduces the overall production cost. Tissue paper released a significant amount of fermentable sugar that contain the highest cellulose content and cellulose content is necessary for sugar extraction. In conclusion, lignocellulosic waste paper can be used to obtain glucose syrups of high purity in glucose that can be subsequently used for commercial or industrial purposes. Research is needed to make this process economically feasible. In future, this approach can be used for the sustainable energy production of bioethanol.

\section{Acknowledgement}

This work is supported by Higher Education Commission (HEC) "Pakistan under the research the project No. 21-441 SRGP/R\&D/HEC/20144.

\section{Conflict of Interest}

Authors declared that these is no conflict of interest.

\section{References}

1. L. Wang, M. Sharifzadeh, R. Templer and R. J. Murphy, Appl. Energ., 111 (2013) 1172.

https://doi.org/10.1016/j.apenergy.2012.08.0 $\underline{48}$

2. $\bar{M}$. Guerfali, A. Saidi, A. Gargouri and H. Belghith, Appl. Biochem. Biotechnol., 175 (2015) 25. https://doi.org/10.1007/s12010-014$\underline{1243-1}$
3. A. Poladyan L. Margaryan K. Trchounian and A. Trchounian. Int. J. Hydrog. Energ., 45 (2020) 286.

https://doi.org/10.1016/j.ijhydene.2019.1 $\underline{0.246}$

4. A. Al-Azkawi, A. Elliston, S. Al-Bahry, and N. Sivakumar, Biofuel Bioprod. Bior., (2019) 1106. https://doi.org/10.1002/bbb.1983

5. J. W. Day, J. Barras, E. Clairain, J. Johnston, D. Justic, G. P. Kemp, J. Young Ko, R. Lane, W. J. Mitsch, G. Steyer, P. Templet and A. YañezArancibia, Ecol. Eng., 24 (2005) 253. https://doi.org/10.1016/j.ecoleng.2004.1 $\underline{1.015}$

6. M. Höök and X. Tang, Energ. Policy, 52 (2013) 797.

https://doi.org/10.1016/j.enpol.2012.10.046

7. J. L. Stephen and B. Periyasamy, Fuel, 214 (2018) 623.

https://doi.org/10.1016/j.fuel.2017.11.042

8. N. Srivastava, K. Mishra, M. Srivastava, K. R. Srivastava V. K. Gupta, P. W. Ramteke and P. K. Mishra, New and Future Developments in Microbial Biotechnology and Bioengineering: Elsevier; $1^{\text {st }}$ Edition Elsevier, (2019) 29. https://doi.org/10.1016/B978-0-44464223-3.00003-5

9. A. Hepbasli and O. Ozgener, Renew. Sust. Energ. Rev., 8 (2004) 47. https://doi.org/10.1016/j.rser.2003.10.006

10. M. B. Tonetta, S. Guran, D. Specca, B. Cowan, C. Sipos and J. Melillo, Ind. Biotechnol., 10 (2014) 404. https://doi.org/10.1089/ind.2014.0023

11. J. Goldemberg, Science, 315 (2007) 808. DOI: $10.1126 /$ science. 1137013

12. J. K. Saini, R. Saini and L. Tewari, Biotech., 5 (2015) 337. https://doi.org/10.1007/s13205-014$\underline{0246-5}$

13. A. Demirbas. Energ. Convers. Manag., 50 (2009) 2239.

https://doi.org/10.1016/j.enconman.2009.05. $\underline{010}$ 
14. N. Sriram and M. Shahidehpour. Renewable biomass energy. Paper presented at: IEEE Power Engineering Society General Meeting, (2005) 612. doi: 10.1109/PES.2005.1489459.

15. N. Mosier, C. Wyman, B. Dale, R. Elander, Y. Y. Lee, M. Holtzapple and M. Ladisch, Bioresour. Technol., 96 (2005) 673.

https://doi.org/10.1016/j.biortech.2004.0 $\underline{6.025}$

16. T. Eggeman and R. T. Elander, Bioresour. Technol., 96 (2005) 2019. https://doi.org/10.1016/j.biortech.2005.0 $\underline{1.017}$

17. B. C. Saha, L. B. Iten, M. A. Cotta and Y. V. Wu, Biotechnol. Prog., 21 (2005) 3693.

https://doi.org/10.1021/bp049564n

18. M. R. Wilkins, W. W. Widmer, K. Grohmann, Process Biochem., 42. 12 (2007) 1614.

https://doi.org/10.1016/j.procbio.2007.09.006

19. Y. B. Huang and Y. Fu, Green Chem., 1 (2013) 1095.

https://doi.org/10.1039/C3GC40136G

20. Y. Sun and J. Cheng, Bioresour. Technol., 83 (2002) 1. https://doi.org/10.1016/S0960$\underline{\text { 8524(01)00212-7 }}$

21. U. Asghar, M. Irfan, M. Nadeem, R. Nelofer and Q. Syed, Iran.J. Sci. Technol. Trans. A., 41 (2017) 659. https://doi.org/10.1007/s40995-0170284-z

22. R. Khandeparkar and N. B. Bhosle, Bioresour. Technol., 98 (2007) 897. https://doi.org/10.1016/j.biortech.2006.0 2.037

23. M. Salam, P. C. Pondith, A. Islam, M. R. Khan, M. R. Uddin and M. Islam, Chem. Eng. J., 28 (2013) 27. https://doi.org/10.3329/jce.v28i1.18107

24. R. Purwadi, C. Niklasson, M. J. Taherzadeh, Biotechnol., 114 (2004) 187.

https://doi.org/10.1016/j.jbiotec.2004.07.006
25. F. Fazio, M. C. Bryan, O. Blixt, J. C. Paulson, C. H. Wong, J. Am. Chem. Soc., 124 (2002) 14397. https://doi.org/10.1021/ja020887u

26. Y. H. Kim, S. M. Lee, H. W. Lee and J. W. Lee, Bioresour. Technol., 116 (2012) 120.

https://doi.org/10.1016/j.biortech.2012.0 $\underline{4.033}$

27. T. Foyle, L. Jennings and P. Mulcahy, Bioresour. Technol., 98 (2007) 3026. https://doi.org/10.1016/j.biortech.2006.1 $\underline{0.013}$

28. J. J. Young, C. M. Suk and Y. J. Kyung, J. Korean Wood Sci. Technol., 41 (2013) 87. https://doi.org/10.5658/WOOD.2013.41.2.87

29. Y. Y. Lee, Z. Wu and R. W. Torget, Bioresour. Technol., 71 (2000) 29. https://doi.org/10.1016/S09608524(99)00053-X

30. S. A. Byadgi and P. B. Kalburg, Procedia Environ. Sci., 35 (2016) 555. https://doi.org/10.1016/j.proenv.2016.07.040

31. R. Gupta and Y. Y. Lee, Bioresour. Technol.,101 (2010) 8185. https://doi.org/10.1016/j.biortech.2010.0 $\underline{5.039}$

32. A. K. Dubey, P. K. Gupta, N. Garg, S. Naithani, Carbohydr. Polym., 88 (2012) 825.

https://doi.org/10.1016/j.carbpol.2012.01 .004

33. A. Elliston, S. R. A. Collins, D. R. Wilson, L. N. Roberts, K. W. Waldron, Bioresour. Technol., 134 (2013) 117. https://doi.org/10.1016/j.biortech.2013.0 1.084

34. R. C. Kuhad, G. Mehta, R. Gupta, K. K. Sharma, Biomass Bioenerg., 34 (2010) 1189.

https://doi.org/10.1016/j.biombioe.2010. $\underline{03.009}$

35. H. G. da Mota and E. R. Gouveia, Waste Biomass Valori., 7 (2016) 507. https://doi.org/10.1007/s12649-0159475-Z 